\begin{tabular}{ll}
\hline \hline MINING AND METALLURGY INSTITUTE BOR & ISSN: 2334-8836 (Štampano izdanje) \\
UDK: 622 & ISSN: 2406-1395 (Online) \\
\hline \hline
\end{tabular}

Zoran M. Milićevic * Dragan D. Marinović**, Nebojša Z. Djokić, Ljiljana J. Arsić*

\title{
IMPACT THE CONCENTRATION OF SUSPENDED PARTICLES PM10 ON THE AIR POLLUTION IN THE CITY OF KRALJEVO (SERBIA)
}

\section{Abstract}

This paper analyzes the concentration of PM10 suspended particles in the air sampled from one measuring spot in the downtown area of the City of Kraljevo. The analysis includes 1358 samples (one sample per 24 hours) in the period 2012-2015. Sampling of the ambient air and analysis of samples were carried out by the standard methods. Gravimetric method of analyzed samples has shown that the suspended particle concentration was in the interval of 2.17-405.43 $\mu \mathrm{g} / \mathrm{m}^{3}$. Apart from that, $420 \mathrm{sam}$ ples, or $30.9 \%$ of the analyzed samples, exceeded the limit and tolerance values. As $95 \%$ of these cases took place during the heating season, it can be concluded that the manner of heating of the City of Kraljevo plays a dominant role in increased air pollution by the suspended particles PM10. The increased level of air pollution by these particle has a negative impact on human health and eco-system of this City.

Keywords: air pollution, suspended particles PM10, gravimetric method

\section{INTRODUCTION}

Air pollution by suspended particles includes tiny particles that may be in a solid or liquid aggregate state. Among them, the ones reaching the deepest parts of lungs are of a particular importance, and the diameter of those particles is smaller than $10 \mu \mathrm{m}$. These particles are classified into three categories:

1) particles smaller than $10 \mu \mathrm{m}$ marked as PM10, called the coarse suspended particles,

2) particles smaller than $2.5 \mu \mathrm{m}$ marked as PM2.5, called the fine suspended particles, and

3) particles smaller than $0.1 \mu \mathrm{m}$ marked as PM0.1, called the ultra-fine suspended particles [1].
The coarse dispersed particles PM10 usually represent a mixture of smoke, dust, soot, acids, salts and other substances. They may be of urban or rural origin, and they originate from: industrial plants, motor vehicles, boiler room and furnaces for burning of solid fuels, dust from construction sites, landfills and agricultural regions, fire, etc.

The World Health Organization and World Meteorological Organization established the system of monitoring the quality of human environment in order to protect the environment. The Environmental Protection Agency (EPA) labeled the solid particles, sulphur dioxide, carbon monoxide, nitrogen oxides, ozone and heavy metals as the main air pollutants and defined standards for them

\footnotetext{
*University of Pristina, Faculty of Economics, Kolasinska 156, 38220 Kosovska Mitrovica, Serbia, e-mail: zoran.milicevic@pr.ac.rs

** Public Health Institute, Slobodana Penezica 16, 36000 Kraljevo, Serbia
} 
to the aim of of protection the human health and ecosystems. These substances are the primary polluting substances with the varying concentrations in accordance to the weather conditions (concentrations are the highest during autumn and winter), and much more dangerous the secondary polluting substances are created by their interaction [2].

Floating particles of dust, ash, liquid drops of smoke and other condensed gaseous compounds suspended in the air (aerosols) are considered to be the most hazardous air pollutants [3]. Results of the study were conducted in three European countries (Austria, Switzerland and Germany) in which about 75 million people live, indicate that the exposure to respiratory particles accounts for about 40,000 deaths per year [4]. Still, some researcher believe that the increase of suspended particles in the air by $10 \mu \mathrm{g} / \mathrm{m}^{3}$ increases mortality by $0.4-1 \%$ $[5,6]$.

Concentration of PM10 suspended particles is monitored in the EU countries as a part of regular monitoring. According to the applicable legislation, the daily mean for concentration of PM10 suspended particles is $50 \mu \mathrm{g} / \mathrm{m}^{3}$, and it may not be exceeded for more than 35 days a year, and the permitted annual mean for PM10 is $40 \mu \mathrm{g} / \mathrm{m}^{3}[7,8]$.

Limit and tolerable values for the PM10 suspended particle fraction in the Republic of Serbia are regulated by the Regulation on Conditions for Monitoring and Requirements for the Air Quality [9]. According to this Regulation, the limit value for PM10 suspended particle fraction in Serbia is 50 $\mu \mathrm{g} / \mathrm{m}^{3}$, whereas the tolerable value for the same parameter is $75 \mu \mathrm{g} / \mathrm{m}^{3}$. At the annual level, the value for PM10 suspended particle fraction is $40 \mu \mathrm{g} / \mathrm{m}^{3}$, whereas the tolerable value is $48 \mu \mathrm{g} / \mathrm{m}^{3}$.

As the suspended particles are the main air pollutants, there is a need to monitor them in order to undertake the preventive measures for protection the human health and ecosystems. The analyses of air pollution impact on human health have been performed in certain cities in our country $[10,11,12]$, but there was no detailed research on the national level.

The aim of this paper is to analyze the level of air pollution by suspended particles PM10 in the City of Kraljevo. This City is located at the central part of the Republic of Serbia, at $43^{\circ} 43^{\prime}$ north latitude and $20^{\circ} 41^{\prime}$ east longitude, at the altitude of about 206 $\mathrm{m}$. It is located in a valley between the Vlach, Sumadija and Kopaonik mountain ranges, and lies on three rivers - Ibar, Zapadna Morava and Ribnica. According to the Census of 2011, there are 68,749 inhabitants in the City itself, and 125,488 inhabitants on the whole municipal territory [13].

Concentrations of PM10 suspended particles in 1358 samples sampled almost every day in the period 2012-2015 were determined applying the standard methods. A particular attention was paid to an analysis of samples from a six-month period of heating season in which the concentration of these particles was several times higher than the limit and tolerable values.

\section{EXPERIMENTAL PART}

Within this paper, the concentrations of PM10 suspended particles at one measuring spot were determined almost every day within four years. The selected measuring spot is in the downtown area of the City of Kraljevo at $43^{\circ} 43^{\prime} 21.76^{\prime \prime}$ north latitude and $20^{\circ} 41^{\prime} 33.03^{\prime \prime}$ east longitude. As there are no industrial plants near the measuring spot, the main source of air pollution is the boiler room of the City Heating Plant, heating both residential and commercial facilities, and it is $300 \mathrm{~m}$ distant from the measuring spot. The significant sources of air pollution are also numerous private furnaces and road traffic. The average frequency of vehicles is 
about 2000 vehicles per hour in both directions. There are two crossroads at a distance of about $150-250 \mathrm{~m}$ from the measuring spot. All the streets near the measuring spot are asphalted, they are 5-10 $\mathrm{m}$ wide, and their maintenance is at a satisfactory level.

Sampling of the ambient air and laboratory testing were performed by the standard methods [14]. Measuring quality check, manner of processing and presentation of results and evaluation of their reliability and credibility were done in accordance with the stipulated methods of measurement and standard requirements [15].

SEQ47/50 sampler made by Sven Leckel Company from Germany was used for sampling of ambient air, equipped with corresponding air intake pipes and corresponding inputs for sampling of the PM10 suspended particles, directly connected to the Glass fiber filter dia 47/50 mm Whatman and the flow control device.

A filter paper of the corresponding size, previously measured on the analytical balance measuring at five decimals, is placed in the sampler. The filter paper should be previously conditioned in a special room in which the constant temperature $(20 \pm 1)^{\circ} \mathrm{C}$ and corresponding humidity (45-50)\% RH are maintained [14]. After 48 and 72 hours, the filter paper is measured and then transported in a special container and placed into a sampling machine of ambient air.

After passing of air with certain flow through the filter paper during 24 hours, the filter is taken off and transported back in the same container to the lab to be conditioned in the room for measuring of PM10 suspended particles, where it is measured after 48 and 72 hours. Concentration of fraction of PM10 suspended particles is calculated according to the following formula:

$$
C\left(\mu g / m^{3}\right)=\left(m_{2}-m_{1}\right) / F \cdot t
$$

where:

$C$ - concentration of the fraction of PM10 suspended particles $\left(\mu \mathrm{g} / \mathrm{m}^{3}\right)$;

$m_{1}$ - empty filter paper mass $(\mu \mathrm{g})$;

$m_{2}$ - filter paper mass after sampling $(\mu \mathrm{g})$;

$F$ - flow volume in the ambient conditions $\left(\mathrm{m}^{3} / \mathrm{h}\right)$, and

$t$ - sampling period (h).

Temperature and humidity are measured by a thermohygrometer and recorded in a computer.

This paper presents the concentrations of PM10 suspended particles in the period 2012-2015, per year and month, their minimum and maximum values, mean values, the number of days above the limit value, and the number of days above the tolerable value.

\section{RESULTS AND DISCUSSION}

This paper analyzes the results of determining the concentration of PM10 suspended particles that included 1,358 samples (one sample every 24 hours), sampled at the location of the City of Kraljevo in the period 2012-2015.

Results of concentration of these particles in the tested samples were obtained by the gravimetric analysis, and minimum and maximum values, average annual values, and the number of days above limit and tolerable values are presented in Table 1 . According to this Table, the minimum concentration of these particles was $2.17 \mu \mathrm{g} / \mathrm{m}^{3}$ in 2015, and the maximum value was $405.43 \mu \mathrm{g} / \mathrm{m}^{3}$ in 2012 . Their average annual values were slightly lower in 2014 . $48.13 \mu \mathrm{g} / \mathrm{m}^{3}$, and approximately the same $\left(53.74-53.90 \mu \mathrm{g} / \mathrm{m}^{3}\right)$ in 2012,2013 , and 2015. 
Table 1 Annual review the concentrations of suspended particles PM10 in the period 2012-2015

\begin{tabular}{|l|c|c|c|c|c|}
\hline & & \multicolumn{4}{|c|}{ PM10 suspended particles } \\
\hline Year & & $\mathbf{2 0 1 2}$ & $\mathbf{2 0 1 3}$ & $\mathbf{2 0 1 4}$ & $\mathbf{2 0 1 5}$ \\
\hline $\begin{array}{l}\text { Number of days in the year } \\
\text { when measuring was per- } \\
\text { formed }\end{array}$ & & 315 & 335 & 352 & 356 \\
\hline $\mathrm{X}-$ annual $\left(\mu \mathrm{g} / \mathrm{m}^{3}\right)$ & & 53.90 & 53.74 & 48.13 & 53.82 \\
\hline Min $\left(\mu \mathrm{g} / \mathrm{m}^{3}\right)$ & & 7.97 & 2.42 & 7.06 & 2.17 \\
\hline Max $\left(\mu \mathrm{g} / \mathrm{m}^{3}\right)$ & & 405.43 & 361.95 & 319.92 & 327.17 \\
\hline Above limit value-daily & Number of days & 52 & 45 & 40 & 45 \\
\cline { 2 - 6 } & $\%$ & 16.5 & 13.4 & 11.4 & 12.6 \\
\hline $\begin{array}{l}\text { Above tolerable value- } \\
\text { daily }\end{array}$ & Number of days & 48 & 62 & 52 & 76 \\
\hline
\end{tabular}

Considering the permitted values of PM10 suspended particles in the air, it may be stated that $30.9 \%$ of analyzed samples are above the permitted level, on average. Out of 1,358 analyzed samples, exceeding the permitted value was identified in 420 samples, whereby values were higher than the permitted limit values in 182 samples, and higher than the permitted tolerable values in 238 .

In order to establish the influence of season on concentration of PM10 suspended particles in the air, it is believed that it would be of interest to analyze the results of measuring of these particles per month in the period 2012-2015 (Tables 2 and 3). There is an apparent difference in the content of these particles depending on month and year of their measuring. Regarding the similarity of results per season, the discussion of results is simplified and includes one month from every season: January, April, July and October.

Analysis of the results for January indicates that the highest values for the total concentration $\left(3042.51 \mu \mathrm{g} / \mathrm{m}^{3}\right)$, the highest maximum daily concentrations (258.69 $\left.\mu \mathrm{g} / \mathrm{m}^{3}\right)$, the highest mean monthly concentrations $\left(101.42 \mu \mathrm{g} / \mathrm{m}^{3}\right)$ as well as the lowest minimum concentrations $\left(16.30 \mu \mathrm{g} / \mathrm{m}^{3}\right)$ were recorded in 2015, compared to 2012 , 2013 and 2014. In the same month of 2013 , 2014 , and 2015, a large number of days (2021) with concentrations of these particles above limit and tolerable values were recorded.

In April of the analyzed period of 20122015 , the lower concentrations of suspended particles PM10 were recorded than in January. The total monthly concentration of these particles was in the interval of 887.39 - $1008.46 \mu \mathrm{g} / \mathrm{m}^{3}$, and the average concentration in the interval of $30.25-36.02 \mu \mathrm{g} / \mathrm{m}^{3}$. In the same month of 2012, both minimum $\left(7.97 \mu \mathrm{g} / \mathrm{m}^{3}\right)$ and maximum $\left(69.92 \mu \mathrm{g} / \mathrm{m}^{3}\right)$ concentrations of these particles were recorded. The number of days above the limit value was recorded in the interval of 2-3 days, and there were no days above the daily tolerable value. 
Table 2 Monthly review the concentrations of suspended particles PM10 in the period January - June from 2012-2015

\begin{tabular}{|c|c|c|c|c|c|}
\hline Month & & 2012 & 2013 & 2014 & 2015 \\
\hline \multirow{6}{*}{ January } & Total $\left(\mu \mathrm{g} / \mathrm{m}^{3}\right)$ & 1403.54 & 2570.19 & 2633.02 & 3042.51 \\
\hline & $\operatorname{Max}\left(\mu \mathrm{g} / \mathrm{m}^{3}\right)$ & 168.47 & 232.06 & 210.14 & 258.69 \\
\hline & $\operatorname{Min}\left(\mu \mathrm{g} / \mathrm{m}^{3}\right)$ & 31.15 & 18.11 & 27.35 & 16.30 \\
\hline & X-monthly $\left(\mu \mathrm{g} / \mathrm{m}^{3}\right)$ & 77.97 & 91.79 & 87.77 & 101.42 \\
\hline & Number of days above limit value & 4 & 5 & 7 & 4 \\
\hline & Number of days above tolerable value & 7 & 16 & 14 & 16 \\
\hline \multirow{6}{*}{ February } & Total $\left(\mu \mathrm{g} / \mathrm{m}^{3}\right)$ & 2820.76 & 1427.26 & 1996.41 & 2014.75 \\
\hline & $\operatorname{Max}\left(\mu \mathrm{g} / \mathrm{m}^{3}\right)$ & 267.21 & 117.21 & 185.59 & 169.93 \\
\hline & $\operatorname{Min}\left(\mu \mathrm{g} / \mathrm{m}^{3}\right)$ & 41.30 & 17.39 & 27.13 & 31.34 \\
\hline & X-monthly $\left(\mu \mathrm{g} / \mathrm{m}^{3}\right)$ & 128.22 & 52.86 & 71.30 & 71.95 \\
\hline & Number of days above limit value & 5 & 14 & 4 & 12 \\
\hline & Number of days above tolerable value & 15 & 2 & 11 & 7 \\
\hline \multirow{6}{*}{ March } & Total $\left(\mu \mathrm{g} / \mathrm{m}^{3}\right)$ & 1888.8 & 1090.10 & 1332.32 & 1520.69 \\
\hline & $\operatorname{Max}\left(\mu \mathrm{g} / \mathrm{m}^{3}\right)$ & 131.15 & 84.78 & 91.66 & 107.24 \\
\hline & $\operatorname{Min}\left(\mu \mathrm{g} / \mathrm{m}^{3}\right)$ & 36.41 & 17.39 & 19.02 & 16.66 \\
\hline & X-monthly $\left(\mu \mathrm{g} / \mathrm{m}^{3}\right)$ & 60.93 & 38.93 & 45.94 & 49.05 \\
\hline & Number of days above limit value & 18 & 3 & 9 & 13 \\
\hline & Number of days above tolerable value & 6 & 3 & 3 & 2 \\
\hline \multirow{6}{*}{ April } & Total $\left(\mu \mathrm{g} / \mathrm{m}^{3}\right)$ & 1008.46 & 965.98 & 887.39 & 907.37 \\
\hline & $\operatorname{Max}\left(\mu \mathrm{g} / \mathrm{m}^{3}\right)$ & 69.92 & 54.16 & 59.05 & 47.83 \\
\hline & $\operatorname{Min}\left(\mu \mathrm{g} / \mathrm{m}^{3}\right)$ & 7.97 & 20.10 & 18.11 & 12.13 \\
\hline & X-monthly $\left(\mu \mathrm{g} / \mathrm{m}^{3}\right)$ & 36.02 & 34.50 & 32.87 & 30.25 \\
\hline & Number of days above limit value & 3 & 2 & 2 & 0 \\
\hline & Number of days above tolerable value & 0 & 0 & 0 & 0 \\
\hline \multirow{6}{*}{ May } & Total $\left(\mu \mathrm{g} / \mathrm{m}^{3}\right)$ & 766.71 & 813.40 & 642.22 & 792.12 \\
\hline & $\operatorname{Max}\left(\mu \mathrm{g} / \mathrm{m}^{3}\right)$ & 49.81 & 61.17 & 39.97 & 38.58 \\
\hline & $\operatorname{Min}\left(\mu \mathrm{g} / \mathrm{m}^{3}\right)$ & 14.31 & 12.86 & 7.06 & 14.13 \\
\hline & X-monthly $\left(\mu \mathrm{g} / \mathrm{m}^{3}\right)$ & 28.40 & 30.13 & 22.15 & 25.55 \\
\hline & Number of days above limit value & 0 & 3 & 0 & 0 \\
\hline & Number of days above tolerable value & 0 & 0 & 0 & 0 \\
\hline \multirow{6}{*}{ June } & Total $\left(\mu \mathrm{g} / \mathrm{m}^{3}\right)$ & 679.65 & 733.91 & 812.38 & 687.04 \\
\hline & $\operatorname{Max}\left(\mu \mathrm{g} / \mathrm{m}^{3}\right)$ & 34.96 & 46.92 & 58.51 & 39.49 \\
\hline & $\operatorname{Min}\left(\mu \mathrm{g} / \mathrm{m}^{3}\right)$ & 14.67 & 15.94 & 18.29 & 13.40 \\
\hline & X-monthly $\left(\mu \mathrm{g} / \mathrm{m}^{3}\right)$ & 23.44 & 28.23 & 28.01 & 22.90 \\
\hline & Number of days above limit value & 0 & 0 & 1 & 0 \\
\hline & Number of days above tolerable value & 0 & 0 & 0 & 0 \\
\hline
\end{tabular}


Table 3 Monthly review the concentrations of suspended particles PM10 in the period July-December from 2012-2015

\begin{tabular}{|c|c|c|c|c|c|}
\hline Month & & 2012 & 2013 & 2014 & 2015 \\
\hline \multirow{6}{*}{ July } & $\operatorname{Total}\left(\mu \mathrm{g} / \mathrm{m}^{3}\right)$ & 813.66 & 817.59 & 760.19 & 956.57 \\
\hline & $\operatorname{Max}\left(\mu \mathrm{g} / \mathrm{m}^{3}\right)$ & 38.58 & 45.10 & 40.21 & 79.52 \\
\hline & $\operatorname{Min}\left(\mu \mathrm{g} / \mathrm{m}^{3}\right)$ & 17.21 & 2.42 & 16.12 & 18.11 \\
\hline & X-monthly $\left(\mu \mathrm{g} / \mathrm{m}^{3}\right)$ & 29.06 & 29.20 & 26.21 & 31.88 \\
\hline & Number of days above limit value & 0 & 0 & 0 & 0 \\
\hline & Number of days above tolerable value & 0 & 0 & 0 & 1 \\
\hline \multirow{6}{*}{ August } & $\operatorname{Total}\left(\mu \mathrm{g} / \mathrm{m}^{3}\right)$ & 844.89 & 906.40 & 839.85 & 887.63 \\
\hline & $\operatorname{Max}\left(\mu \mathrm{g} / \mathrm{m}^{3}\right)$ & 61.23 & 43.84 & 40.39 & 50.18 \\
\hline & $\operatorname{Min}\left(\mu \mathrm{g} / \mathrm{m}^{3}\right)$ & 12.86 & 19.38 & 9.96 & 11.77 \\
\hline & X-monthly $\left(\mu \mathrm{g} / \mathrm{m}^{3}\right)$ & 30.17 & 31.26 & 27.09 & 28.63 \\
\hline & Number of days above limit value & 4 & 0 & 0 & 1 \\
\hline & Number of days above tolerable value & 0 & 0 & 0 & 0 \\
\hline \multirow{6}{*}{ September } & $\operatorname{Total}\left(\mu \mathrm{g} / \mathrm{m}^{3}\right)$ & 853.30 & 782.71 & 955.29 & 855.86 \\
\hline & $\operatorname{Max}\left(\mu \mathrm{g} / \mathrm{m}^{3}\right)$ & 41.12 & 51.99 & 55.07 & 53.62 \\
\hline & $\operatorname{Min}\left(\mu \mathrm{g} / \mathrm{m}^{3}\right)$ & 18.29 & 11.05 & 17.93 & 2.17 \\
\hline & X-monthly $\left(\mu \mathrm{g} / \mathrm{m}^{3}\right)$ & 30.48 & 27.95 & 31.84 & 28.53 \\
\hline & Number of days above limit value & 0 & 1 & 1 & 2 \\
\hline & Number of days above tolerable value & 0 & 0 & 0 & 0 \\
\hline \multirow{6}{*}{ October } & $\operatorname{Total}\left(\mu \mathrm{g} / \mathrm{m}^{3}\right)$ & 1196.06 & 1700.58 & 1291.78 & 1280.88 \\
\hline & $\operatorname{Max}\left(\mu \mathrm{g} / \mathrm{m}^{3}\right)$ & 101.63 & 115.03 & 92.02 & 99.82 \\
\hline & $\operatorname{Min}\left(\mu \mathrm{g} / \mathrm{m}^{3}\right)$ & 14.85 & 8.69 & 14.85 & 10.14 \\
\hline & X-monthly $\left(\mu \mathrm{g} / \mathrm{m}^{3}\right)$ & 42.72 & 58.64 & 44.54 & 41.32 \\
\hline & Number of days above limit value & 7 & 9 & 8 & 4 \\
\hline & Number of days above tolerable value & 1 & 10 & 3 & 3 \\
\hline \multirow{6}{*}{ November } & Total $\left(\mu \mathrm{g} / \mathrm{m}^{3}\right)$ & 1596.24 & 1556.85 & 1566.34 & 3394.80 \\
\hline & $\operatorname{Max}\left(\mu \mathrm{g} / \mathrm{m}^{3}\right)$ & 176.08 & 191.12 & 109.05 & 243.11 \\
\hline & $\operatorname{Min}\left(\mu \mathrm{g} / \mathrm{m}^{3}\right)$ & 15.57 & 16.66 & 17.57 & 20.83 \\
\hline & X-monthly $\left(\mu \mathrm{g} / \mathrm{m}^{3}\right)$ & 59.12 & 57.66 & 52.21 & 113.16 \\
\hline & Number of days above limit value & 3 & 4 & 5 & 6 \\
\hline & Number of days above tolerable value & 6 & 6 & 6 & 20 \\
\hline \multirow{6}{*}{ December } & $\operatorname{Total}\left(\mu \mathrm{g} / \mathrm{m}^{3}\right)$ & 3007.28 & 4974.19 & 3334.55 & 3138.47 \\
\hline & $\operatorname{Max}\left(\mu \mathrm{g} / \mathrm{m}^{3}\right)$ & 405.43 & 361.95 & 319.92 & 327.17 \\
\hline & $\operatorname{Min}\left(\mu \mathrm{g} / \mathrm{m}^{3}\right)$ & 25.54 & 29.34 & 12.13 & 45.65 \\
\hline & $\mathrm{X}$-monthly $\left(\mu \mathrm{g} / \mathrm{m}^{3}\right)$ & 100.24 & 160.46 & 107.57 & 101.24 \\
\hline & Number of days above limit value & 8 & 4 & 3 & 3 \\
\hline & Number of days above tolerable value & 13 & 25 & 15 & 27 \\
\hline
\end{tabular}


July of the analyzed period 2012 - 2015 is characterized by significantly lower concentrations of the PM10 suspended particles. Total monthly concentrations of these particles were in the interval of $760.19-956.57$ $\mu \mathrm{g} / \mathrm{m}^{3}$, and their average concentration was between 26.21 and $31.88 \mu \mathrm{g} / \mathrm{m}^{3}$, whereas only one day above the tolerable value was recorded. In this month, the minimum concentration of $2.49 \mu \mathrm{g} / \mathrm{m}^{3}$ was recorded in 2013 , and the maximum value of 79.52 $\mu \mathrm{g} / \mathrm{m}^{3}$ in 2015.

Results for October of the analyzed period 2012-2015 indicate the increase in concentration of PM10 suspended particle concentration compared to July. It is shown by the following parameters: the total concentration of these particles was in the interval of $1196.06-1700.58 \mu \mathrm{g} / \mathrm{m}^{3}$; the average concentration was in the interval of 41.32 $58.64 \mu \mathrm{g} / \mathrm{m}^{3}$; the number of days above the limit values was recorded in the interval of 4-9 days; and the number of days above the daily tolerable value was recorded in the interval of 1-10 days. In the same month of 2013 , both minimum $\left(8.69 \mu \mathrm{g} / \mathrm{m}^{3}\right)$ and ma- ximum $\left(115.03 \mu \mathrm{g} / \mathrm{m}^{3}\right)$ concentrations of the analyzed particles were recorded.

Analysis of the contents of PM10 suspended particles in the period 2012-2015 resulted in observation that their total maximum concentration $\left(4974.18 \mu \mathrm{g} / \mathrm{m}^{3}\right)$ and their maximum average concentration $\left(160.46 \mu \mathrm{g} / \mathrm{m}^{3}\right)$ were recorded in December 2013 , and that their total minimum concentration $\left(642.22 \mu \mathrm{g} / \mathrm{m}^{3}\right)$, and their minimum average concentration $\left(22.15 \mu \mathrm{g} / \mathrm{m}^{3}\right)$ were recorded in May 2014. Apart from that, the largest number of days (18-30) in which the concentration of these particles was above limit and tolerable values, was recorded in December of the analyzed period, whereby the permitted values were not exceeded in June. These results clearly indicate the difference between concentrations of these particles in the heating season months (October, November, December, January, February and March) and off the heating season (April, May, June, July, August and September). This conclusion is supported by a chart presented in Figure 1 showing the mean concentrations of PM10 suspended particles per month in the period 2012-2015.

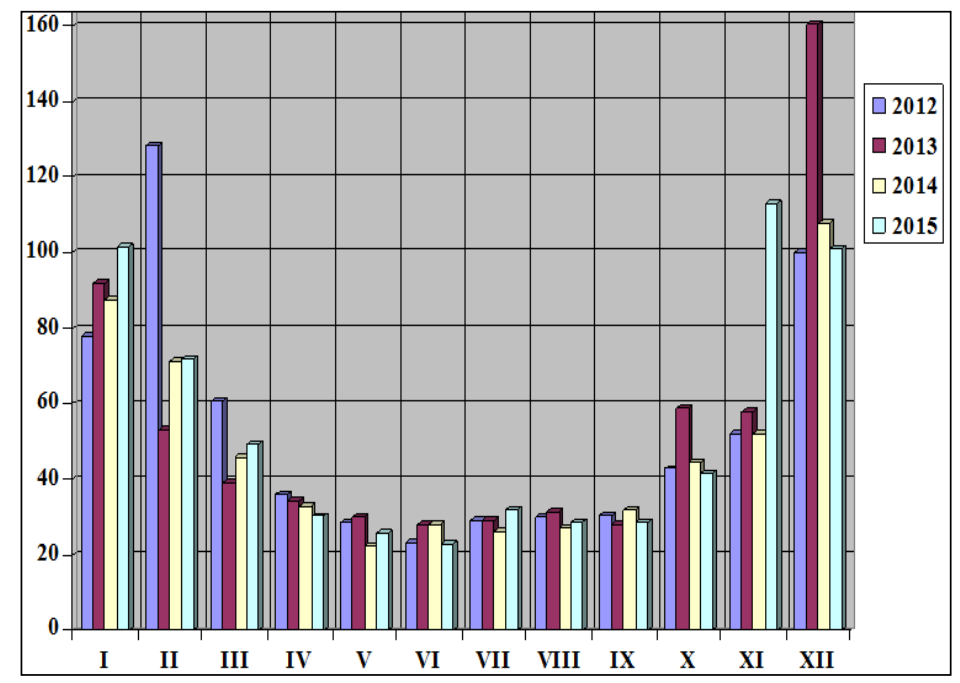

Figure 1 Average monthly concentrations of suspended particles PM10 in the period 2012-2015 
The presence of the additional source of emission (boiler rooms and individual furnaces) during the heating season significantly influenced the increased concentrations of PM10 suspended particles, and the identified average and maximum values are significantly higher than the values off the heating season. Daily concentrations of the analyzed particles exceeded the limit value in more than $50 \%$ measuring during the heating season, and the percentage of measuring with concentrations of this fraction of PM10 suspended particles above the tolerable value is also considerable. Exceeding of limit and tolerable values was recorded during 420 days, out of which 400 days in the period of heating season, and 20 days off the heating season, as presented on a chart in Figure 2. Therefore, PM10 suspended particles signi- ficantly impact the air pollution in the City of Kraljevo. It is verified by their maximum concentration of $405.43 \mu \mathrm{g} / \mathrm{m}^{3}$ (recorded on 26 December 2012), which is as much as eight times higher than the limit value, and more than five times higher than the tolerable value. As much as $30.9 \%$ of the analyzed samples exceed the limit and tolerable values. Out of 420 samples exceeding the limit and tolerable values, as much as $95 \%$ are samples from the heating season, and $5 \%$ are samples from the period outside of the heating season. These data clearly indicate that the technology of fuel combustion in boiler rooms and individual furnaces influences multiple increase in the content of PM10 suspended particles, thereby influencing the increase at the level of air pollution in the City of Kraljevo.

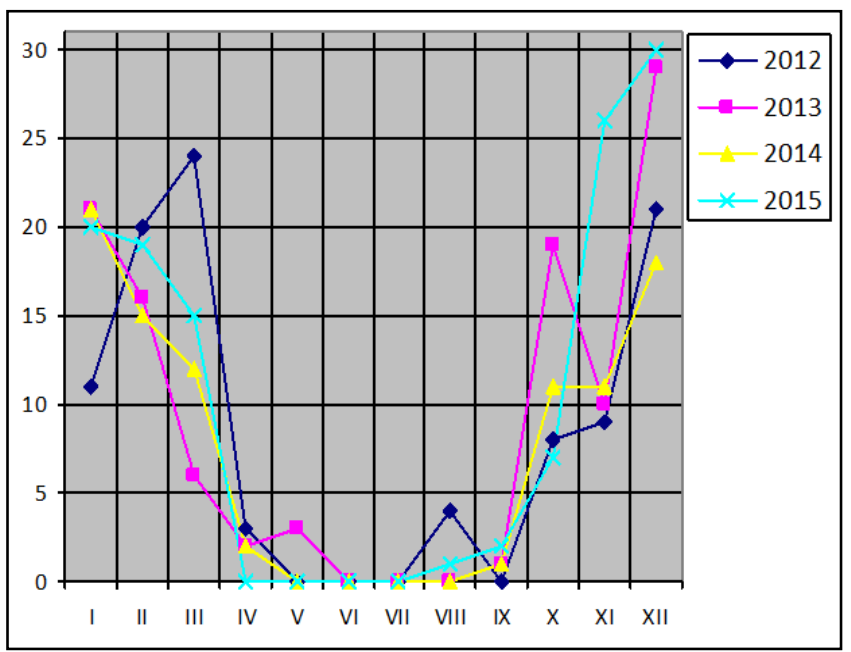

Figure 2 Monthly review the number of days with PM10 concentrations above the limit value and tolerable value in the period 2012-2015

Apart from that, frequency of vehicles passing through the center of the City, as well as a large number of heavy vehicles more than 10 years old significantly contributes to the increase of air pollution in this City, all of which complies with the previous studies in this field $[16,17]$.
These results indicate that the issue of air pollution of the City of Kraljevo needs to be considered as a serious one, as a long-term exposure to the action of PM10 suspended particles has a hazardous impact on human health and ecosystem. 


\section{CONCLUSION}

Analysis of impact of concentration of PM10 suspended particles on air pollution of the City of Kraljevo resulted in the following conclusions:

1) 1,358 samples were analyzed between 2012 and 2015, and the number of samples was from 315 in 2012 to 356 in 2015,

2) Mean annual concentration of PM10 suspended particles was in the interval of 48.13-53.90 $\mu \mathrm{g} / \mathrm{m}^{3}$,

3) Minimum concentration of these particles, recorded in September 2015 was 2.17 $\mu \mathrm{g} / \mathrm{m}^{3}$, and maximum of $405.43 \mu \mathrm{g} / \mathrm{m}^{3}$ was recorded in December 2012,

4) The number of samples that was above the limit value was in the interval of $40-52$, and the number of samples above the tolerable value was in the interval of 48-76,

5) Observed per month, the lowest concentrations of these particles were recorded in June, and the highest in December,

6) Average concentration of these particles in the period of heating season was $75.71 \mu \mathrm{g} / \mathrm{m}^{3}$ and it was significantly higher than the in period off heating season - 28.95 $\mu \mathrm{g} / \mathrm{m}^{3}$,

7) The total number of samples above limit and tolerable values was 420 , out of which 400 samples in heating and 20 samples off the heating season,

8) PM10 suspended particles coming from boiler rooms and individual furnaces play a leading role in the air pollution of the City of Kraljevo,

9) Exceeding of limit and tolerable value of the suspended particles PM10 in 30.9\% of the samples analyzed points to their hazardous impact on the human health and ecosystem of the City of Kraljevo.

\section{REFERENCES}

[1] Grzetic, I., (2016) Suspended and Respiratory Particles in the Urban Areas, Faculty of Chemistry, Belgrade, 4-10 (in Serbian)

[2] Sukalo, D., Arsenovic, B. (2010) Investigation the Effect of Particulate Matter, PM10 Air Quality in the City of Banja Luka, Svarog, No. 1, 213-214 (in Serbian)

[3] Dukovic, J., Bojanic, V. (2000) Air Pollution, Institute of Protection and Ecology, Banja Luka(in Serbian)

[4] Kunzli, N., Kaiser, R., Medina, S., Studnicka, M., Chanel, O., Filliger, P. (2000) Public Health Impact of Outdoor and Traffic Related Air Pollution: A European Assessment, Lancet 356:795-801.

[5] Pope, A., Burnett, T., Thun, J., Calle, E., Krewski, D., Ito, K., and Thurston, D. (2002) Lung Cancer, Cardiopulmonary Mortality and Long-Term Exposure to Fine Particulate Air Pollution, J.Am.Med. Assoc., 287, 1132-1141.

[6] Mokdad, H., Marks, S., Stroup, F., and Gerberding, L. (2004) Actual Causes of Death in the United States, 2000, J. Am. Med. Assoc., 291, 1238-1245.

[7] Council Directive 1999/30/EC Relating to Limit Values for Sulphur Dioxide, Nitrogen Dioxide and Oxides of Nitrogen, Particulate Matter and Lead in Ambient Air, Official Journal of the European Union L 163, 29 June 1999, pp. 41-60.

[8] Directive 2008/50/EC of the European Parliament and of the Council on ambient air quality and cleaner air for Europe, Official Journal of the European Union L 152, 11 June 2008, 
pp. 1-44. Journal of the European Union L 152, 11 June 2008, pp. 1-44.

[9] Directive on Conditions and Requirements for Monitoring the Air Quality, Official Gazette of the Republic of Serbia, Nos. 11/2010, 75/2010 and 63/2013 (in Serbian)

[10] Stankovic, A., Nikic, D., Bogdanovic, D. (2007) Monitoring and Assessment of Air Pollution on the Population Health in the City of Nis, Ecologica, 14: 53-56 (in Serbian)

[11] Nikic D., Bogdanovic D., Nikolic M., Stankovic A., Zivkovic N., Djordjevic A. (2009) Air Quality Monitoring in NIS (SERBIA) and Health Impact Assessment, Environ. Mon. Assess., 158: 499-506.

[12] Milicevic, Z., and Arsic, Lj. (2011) The Impact of Coal Processing Technology on the Environment, Facta Universitatis, Series: Economics and Organization Vol. 8, No 3, 321-330.

[13] Profile of the City of Kraljevo, (2010) Department of Project Management and Local Economic Development, Kraljevo, www.kraljevo.org (in Serbian)
[14] Ambient air - Standard Gravimetric Measurement Method for Determination of PM10 or PM2.5 Mass Concentration of Suspended Particles, SRPS EN 12341: 2015, Official Gazette of the Republic of Serbia, No. 48/15 (in Serbian)

[15] General Requirements for the Competence of Testing and Calibration Laboratories, EN ISO/IEC 17025:2006, Official Gazette of the Republic of Serbia, No. 16/06 (in Serbian)

[16] Nel, A., Xia, T., Mädler, L. and Li, N. (2006) Toxic Potential of Materials at the Nanolevel. Science 311: 622-627.

[17] Souza, D., Vasconcellos, P., Lee, H., Aurela, M., Saarnio, K., Teinilä, K., Hillamo, R. (2014) Composition of PM2.5 and PM10 Collected at Urban Sites in Brazil, Aerosol and Air Quality Research, 14: 168-176.

[18] Milićević, Z., Marinović, D., Gajica, G., Kašanin-Grubin, M., Jovanović, V., Jovančićević, B., (2017) Organic Geochemical Approach in the Identification of Oil-Type Pollutants in Water and Sediments of the River Ibar, J. Serb. Chem. Soc., 82(5) 593-605. 